Diabetologia 8, 385-390 (1972)

(C) by Springer-Verlag 1972

\title{
The Mechanism of Insulin Secretion after Oral Glucose Administration
}

\section{Investigations on the Mechanism of a Reflectoric Insulin Mobilization after Oral Stimulation}

\author{
U. Fischer, H. Hommel, M. Ziegler and E. Jutzi \\ Zentralinstitut für Diabetes „Gerhard Katsch", Karlsburg, German Democratic Republic
}

Received: July 6, 1972, accepted: August 24, 1972

Summary. Previous experiments have shown that in an oral glucose tolerance test insulin is mobilized in the first phase independent of the following hyperglycemia. By giving different amounts of glucose $(0.5-2.0 \mathrm{~g} / \mathrm{kg})$ in conscious trained dogs it was shown that this early phase of insulin secretion was stimulated independently of the administered glucose load by additional mechanisms. These mechanisms, at least partly, were triggered in the nerve endings of the cavity of mouth: their paralysis by mucosal anaesthesia abolished the early IRI-increase in intact animals as well as after feeding glucose to dogs bearing oesophagus fistulas. Spraying sodium cyclamate into the mouth did not produce any IRI-increase. The results indicate that the taste modality "sweet" is not involved in this reflex response. Conditioned reflexes as a consequence of the training programme or of the daily feeding regime were excluded by control experiments.

Mécanisme de la sécrétion d'insuline après administration arale de glucose

III. Recherches sur le mécanisme de mobilisation réflexe de l'insuline après stimulation orale.

Résumé. Des expériences préalables ont montré que dans un test oral de tolérance au glucose l'insuline est mobilisée au cours de la première phase indépendamment de l'hyperglycémie qui suit. Si l'on administre différentes doses de glucose $(0.5-2.0 \mathrm{~g} / \mathrm{kg})$ à des chiens éveillés et entrainés, il apparait que cette première phase de la sécrétion d'insuline est stimulée par des mécanismes additifs indépendamment de la charge de glucose appliquée. Ces mécanismes, au moins en partie, commencent aux terminaisons nerveuses de la cavité buccale: leur paralysie par anesthésie de la muqueuse empêche la première augmentation réflexe d'IRI chez les animaux intacts de même que l'augmentation d'IRI après alimentation simulée de glucose chez des chiens ayant des fistules de l'oesophage. Le fait de pulvériser du cyclamate de sodium dans la cavité buccale ne provoque aucune augmentation d'IRI. Cela signifie que la saveur "sucrée" n'intervient pas dans le mécanisme du réflexe. Les mécanismes des réflexes conditionnés qui sont la conséquence d'un programme d'entraînement ou d'un régime alimentaire journalier étaient exclus par des expériences de contrôle.

Der Mechanismus der Insulinmobilisierung nach oraler Glucosegabe

III. Untersuchungen zum Mechanismus einer reflek. torischen Insulinmobilisierung nach oraler Glucosegabe

Zusammenfassung. Vorangegangene Experimente hatten ergeben, dab bei einem oralen Glucosetoleranztest in einer ersten Phase Insulin unabhängig von der erst darauffolgenden Hyporglykämio freigesetzt wird. Durch Gabe unterschiedlicher Glucosedosen $(0.5-2.0 \mathrm{~g} / \mathrm{kg})$ an wache, trainierte Schäferhunde wird in dieser Mitteilung gezeigt, daß diese erste Phase der Insulinsekretion von der verabfolgten Glucosedosis unabhängig durch zusätzliche Mechanismen stimuliert wird. Diese Mechanismen beginnen zumindest teilweise in Nervenendigungen der Mundhöhle: ihre Betäubung durch Schleimhautanästhesie verhindert den frühzeitigen reflektorischen IRI-Anstieg bei intakten Tieren sowie den gleichen reflektorischen IRI-Anstieg nach Glucosescheinfütterung an Hunde mit Oesophagusfisteln. Einstäubon von NatriumZyklamat in die Mundhöhle ruft keinen IRI-Anstieg hervor. Die Geschmacksrichtung, ,süB " ist also nicht an den reflektorischen Mechanismen beteiligt. Bedingt-reflektorische Vorgänge als Folge des Trainingsprogramms oder der täglichen Nahrungsaufnahme wurden durch Kontrollversuche ausgeschlossen.

Key words: Oral glucose tolerance test, insulin secretion, reflex, glucose doses, receptor, mucosal anaesthesia, cyclamate.

\section{Introduction}

Insulin mobilization after feeding or after oral testing with glucose does not only depend on the rise of blood concentrations of glucose, amino acids, and free fatty acids (FFA), but it is also related to the activity of the "enterohormonal glands" as well as of the vegetative nervous system (Dupré, 1970). Our previous experiments have shown that in conscious dogs after an oral glucose tolerance test (OGTT) the immunoreactive insulin (IRI) in the peripheral venous blood reaches a peak corresponding to the glycemic peak but this peak is preceded by one or two other peaks (Fischer et al., 1972). Similar patterns of insulin secretion can also be produced without any blood glucose increase by sham-feeding glucose or tap water in conscious animals with oesophageal or gastric fistulae (Fischer and Hommel, 1971; Hommel et al., 1972). After intragastric glucose administration, however, it did not occur during the first minutes because the cavity of mouth was avoided by the test solution (Hommel et al., 1972). Two questions should be answered by the experiments reported here: Is there any dose-re. lationship of that early insulin mobilization after OGTT? Can the involvement of local nervous factors be proved in the intact animal? 


\section{Material and Methods}

Animals: Trained pure-breed Alsatian dogs $(7$ males and 16 bitches) with an age of $38.9 \pm 3.2$ months and of a body weight of $28.2 \pm 0.9 \mathrm{~kg}$ were used for 43 tests.

They were starved for $20.2 \pm 0.2 \mathrm{~h}$. The conditions of the experiments and the training pattern are described by Fischer et al. (1972). Three of the animals carried doublebarrelled oesophagus fistulas for at least 6 weeks (of. Hommel et al., 1972).
Finally we had to exclude that the early and transient IRI-rise before the hyperglycemia developed after giving glucose orally, was due to some kind of conditioned refiex. The latter might be produced by training or by normal daily feeding regime. For $2 \mathrm{~min}$ the dogs were shown a fresh meal of meat, or their jaws were slightly irritated mechanically with the plastic tube used in the other experiments for giving test solutions orally. The analytical methods for blood glucose, serum-FFA, and plasma-IRI are given in the previous paper (Fischer et al., 1972).

Calculations: The time curves of concentrations are

Table 1. Blood glucose [mg/100 $\mathrm{ml}], I R I[\mu U / \mathrm{ml}]$ and $F F A$ [ $\mathrm{mmoles} / \mathrm{l}]$ concentrations before and after oral administration of 0.5 or $2.0 \mathrm{~g} / \mathrm{kg}$ glucose

\begin{tabular}{|c|c|c|c|c|c|c|}
\hline $\begin{array}{l}\text { Time } \\
\text { [min] }\end{array}$ & $\begin{array}{l}0.5 \mathrm{~g} / \mathrm{kg}(n=6) \\
\text { Blood glucose }\end{array}$ & IRI & FFA & $\begin{array}{l}2.0 \mathrm{~g} / \mathrm{kg}(n=6) \\
\text { Blood glucose }\end{array}$ & IRI & FFA \\
\hline-30 & $69.8 \pm 6.5$ & $10.8+5.2$ & $363+39$ & $68.0+6.3$ & $24.2+2.9$ & $485+47$ \\
\hline-15 & $70.8 \pm \quad 5.3$ & $15.8 \pm 5.4$ & $397 \pm 57$ & $68.0 \pm 6.6$ & $24.8 \pm 1.0$ & $500 \pm 49$ \\
\hline 0 & $67.7 \pm 5.2$ & $12.5 \pm 5.2$ & $378=56$ & $69.0 \pm 7.4$ & $22.6 \pm 2.2$ & $497+52$ \\
\hline 2.5 & $72.7 \pm 7.9$ & $21.0 \pm 8.1$ & - & $72.8 \pm 8.2$ & $22.0 \pm 5.1$ & - \\
\hline 5.0 & $75.3 \pm 10.7$ & $34.0 \pm 11.0^{\mathrm{a}}$ & $454 \pm 50$ & $73.6 \pm 9.9$ & $22.0 \pm 4.0$ & $553 \pm 59$ \\
\hline 7.5 & $80.8 \pm 11.4$ & $36.8 \pm 10.5^{\mathrm{a}}$ & $\ldots$ & $78.0+10.3$ & $40.6 \pm 4.8^{\mathrm{a}}$ & - \\
\hline 10.0 & $78.2 \pm 12.4$ & $33.3 \pm 3.9^{\mathrm{a}}$ & $400 \pm 48$ & $85.6 \pm 9.7$ & $32.4 \pm 8.7$ & $521 \pm 50$ \\
\hline 12.5 & $88.3 \pm 13.2$ & $51.8+16.0^{\mathrm{a}}$ & - & $87.0 \pm 10.4$ & $39.2 \pm 9.6^{\mathrm{a}}$ & - \\
\hline 15.0 & $89.2+13.4$ & $38.0+7.3^{\mathrm{a}}$ & $333+75$ & $90.2+10.5$ & $37.2+7.0^{\mathrm{a}}$ & $424+71$ \\
\hline 17.5 & $89.3 \pm 12.3^{\mathrm{a}}$ & $49.2+10.7^{a}$ & - & $96.0 \pm 10.2^{\mathrm{a}}$ & $43.4 \pm 4.4^{\mathrm{a}}$ & $x+1 \cdot x$ \\
\hline 20.0 & $81.5 \pm 10.8$ & $40.3 \pm 7.5^{\mathrm{a}}$ & $222+25^{\mathrm{a}}$ & $105.4+13.4^{a}$ & $47.2 \mp 9.9^{\mathrm{a}}$ & $288+92$ \\
\hline 22.5 & $86.8 \pm 9.0^{\mathrm{a}}$ & $45.0^{\perp} 8^{2} 8^{\mathrm{a}}$ & - & $96.8 \pm 12.3^{\mathrm{a}}$ & $42.2 \pm 8.0^{\mathrm{a}}$ & - \\
\hline 25.0 & $81.2+8.2$ & $50.2 \pm 9.0^{\mathrm{a}}$ & $208+52^{a}$ & $106.4 \pm 6.4^{\mathrm{a}}$ & $47.0 \pm 7.9^{\mathrm{a}}$ & $233 \pm 93^{a}$ \\
\hline 30.0 & $81.7 \pm 6.8$ & $41.7 \pm 10.5^{\mathrm{a}}$ & $234 \pm 76$ & $117.2 \pm 4.8^{\mathrm{a}}$ & $55.2 \pm 5.6^{\mathrm{a}}$ & $172 \pm 74^{\mathrm{a}}$ \\
\hline 40.0 & $78.3 \pm 6.2$ & $31.5 \pm 8.3^{\mathrm{a}}$ & $199 \pm 76^{\mathrm{a}}$ & $122.2 \pm 7.3^{\mathrm{a}}$ & $55.8 \pm 10.8^{\mathrm{a}}$ & $137+52^{a}$ \\
\hline 50.0 & $74.0+10.8$ & $31.2+6.9$ & $263+56$ & $109.4+8.8^{a}$ & $50.4+13.3^{\mathrm{a}}$ & $104+34^{a}$ \\
\hline 60.0 & $70.2 \pm 6.6$ & $40.7 \mp 9.8^{\mathrm{a}}$ & $315 \pm 20$ & $120.0 \pm 8.1^{\mathrm{a}}$ & 42.0 士 $6.7 \mathrm{a}$ & $96+29 \mathrm{a}$ \\
\hline 90.0 & $69.0 \pm 7.8$ & $27.3 \pm 7.7$ & $440 \pm 49$ & $89.4 \pm 9.4$ & $40.6 \pm 8.8^{a}$ & $108 \pm 37^{a}$ \\
\hline
\end{tabular}

${ }^{\mathrm{a}}=$ Significant difference from the initial value.

Table 2. Integrated responses of blood glucose, IRI and FFA $(0-90$ min) and insulinogenic index after oral administration of different quantities of glucose without and with preceding mucosal anaesthesia of the mouth

\begin{tabular}{lccccc}
\hline $\begin{array}{l}\text { Glucose dose } \\
{[\mathrm{g} / \mathrm{kg}]}\end{array}$ & $n$ & $\begin{array}{c}\text { Blood glucose area } \\
{\left[\frac{\mathrm{mg} \cdot 90 \mathrm{~min}}{100 \mathrm{ml}}\right]}\end{array}$ & $\begin{array}{c}\text { IRI area } \\
{\left[\frac{\mu \mathrm{U} \cdot 90 \mathrm{~min}}{\mathrm{ml}}\right]}\end{array}$ & $\begin{array}{c}\text { FFA area } \\
{\left[\frac{\mu \text { Moles } \cdot 90 \mathrm{~min}}{1}\right]}\end{array}$ & $\begin{array}{c}\text { Insulinogenic index } \\
0.5\end{array}$ \\
\hline 6 & $965 \pm 387^{\mathrm{b}}$ & $1643 \pm 272$ & $-10764 \pm 1983^{\mathrm{a}}$ & $\mathbf{2 . 9 5} \pm 1.25$ \\
1.0 & 10 & $2153 \pm 616$ & $1927 \pm 350$ & $-21317 \pm 4060$ & $2.72 \pm 1.01$ \\
2.0 & 6 & $2814 \pm 380$ & $1911 \pm 314$ & $-26174 \pm 403$ & $0.78 \pm 0.19^{\mathrm{c}}$ \\
$1.0+$ mucosal & 6 & $977 \pm 610$ & $562 \pm 453^{\mathrm{b}}$ & $-\mathbf{1 4 4 4 0 \pm 4 4 4 5}$ & $0.96 \pm 0.49 \mathrm{c}$ \\
\hline
\end{tabular}

$a=n=4$.

$\mathrm{b}=$ Significant difference to the other tests in that column.

$\mathrm{c}=$ Significant difference to the OGTT with 0.5 or $1.0 \mathrm{~g} / \mathrm{kg}$.

The animals were fed or sharn-fed glucose $0.5,1.0$ or $2.0 \mathrm{~g} / \mathrm{kg}$, dissolved in $50 \mathrm{ml}$ tap water. In some experiments with feeding or sham-feeding glucose $(1.0 \mathrm{~g} / \mathrm{kg})$ the whole cavity of mouth and the upper part of pharynx were sprayed with $6 \mathrm{ml}$ tetracain $2 \%$ (VEB Jenapharm, Jena) at -4 to $-\mathbf{3} \mathrm{min}$ by means of a Zürn-spray. Preceding self-experiments had shown that tetracain was effective from 1 to about $40 \mathrm{~min}$ after spraying (local anaesthesia, with partial paralysis of swallowing). In another group of tests for producing the taste modality "sweet" the jaws of the dogs were sprayed with $25.8 \pm$ $7.3 \mathrm{mg}$ sodium cyclamate (Assugrin ${ }^{\oplus}$, Hermes AG., Zïrich) from -2 to $0 \mathrm{~min}$. According to self-experiments, an intensive sweet sensation occurred immediately and lasted for about $10 \mathrm{~min}$. given $(\overline{\mathrm{x}}+\mathrm{SEM})$. The integrated responses (areas above or below the initial values) of all measured paramoters as well as the time and the extent of different IRI peaks (cf. Fischer et al., 1972) were calculated. The insulinogenic index (Seltzer et al., 1967) was evaluated as the ratio IRIarea: blood glucose area. Differences were tested statistically by t-test (demand for significance $p<1 \%$ ).

\section{Results}

Investigating the dose response we gave 0.5 or 2.0 $\mathrm{g} / \mathrm{kg}$ body weight and compared the findings (Table 1) with those after $1.0 \mathrm{~g} / \mathrm{kg}$ (Fischer et al., 1972). There were measurable increases of blood glucose concentra- 


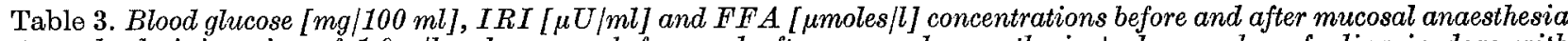
+ oral administration of $1.0 \mathrm{~g} / \mathrm{kg}$ glucose or before and after mucosal anaesthesia + glucose sham-feeding in dogs with oesophageal fistulas

\begin{tabular}{|c|c|c|c|c|c|c|}
\hline \multirow{2}{*}{$\begin{array}{l}\text { Time } \\
\text { [min] }\end{array}$} & \multicolumn{3}{|c|}{ Mucosal anaesthesia + oral feeding $(n=6)$} & \multicolumn{3}{|c|}{ Mucosal anaesthesia + glucose sham-feeding $(n=6)$} \\
\hline & Blood glucose & IRI & FFA & Blood glucose & IRI & FFA \\
\hline-30 & $65.5 \pm 2.7$ & $14.0 \pm 4.1$ & $492 \pm 82$ & $78.1 \pm 8.4$ & $10.4 \pm 5.0$ & $484 \pm 97$ \\
\hline-15 & $67.2 \pm 6.0$ & $17.6 \pm 4.5$ & $468 \pm 74$ & $76.6 \pm 8.2$ & $10.4 \pm 4.4$ & $521 \pm 111$ \\
\hline 0 & $71.0 \pm 9.8$ & $17.0 \pm 6.0$ & $511 \pm 71$ & $77.1 \pm 4.3$ & $11.2 \pm 6.7$ & $486 \pm 80$ \\
\hline 2.5 & $74.2 \pm 8.4$ & $16.8 \pm 4.7$ & -+ & $72.3 \pm 4.4$ & $10.4 \pm 6.4$ & -- \\
\hline 5.0 & $75.4 \pm 3.1$ & $12.3 \pm 3.2$ & $544 \pm 97$ & $73.6 \pm 6.4$ & $8.0 \pm 4.0$ & $609 \pm 96$ \\
\hline 7.5 & $81.2 \pm 5.9$ & $16.0 \pm 5.4$ & - & $79.3 \pm 7.4$ & $10.0 \pm 6.0$ & - \\
\hline 10.0 & $87.0 \pm 8.0$ & $19.0 \pm 4.1$ & $534 \pm 73$ & $76.6 \pm 5.6$ & $12.2 \pm 7.0$ & $583 \pm 121$ \\
\hline 12.5 & $84.0 \pm 5.9$ & $25.6 \pm \quad 5.8$ & - & $84.0 \pm 7.2$ & $10.4 \pm 6.4$ & - \\
\hline 15.0 & $89.8 \pm 7.5$ & $28.1 \pm \quad 5.6$ & $449 \pm 75$ & $78.1 \pm 4.4$ & $11.2 \pm 7.0$ & $572 \pm 104$ \\
\hline 17.5 & $90.0 \pm 6.3^{\mathrm{a}}$ & $40.3 \pm 9.5^{a}$ & -7 & $83.3 \pm 5.2$ & $13.6 \pm 9.6$ & $=-$ \\
\hline 20.0 & $81.0 \pm 5.7$ & $38.3 \pm 8.8^{\mathrm{a}}$ & $426 \pm 88$ & $82.1 \pm 6.0$ & $12.4 \pm 7.4$ & $532 \pm 118$ \\
\hline 22.5 & $96.1 \pm 8.0^{\mathrm{a}}$ & $52.5 \pm 12.6^{\mathrm{a}}$ & - & $82.5 \pm 6.2$ & $11.0 \pm 6.8$ & - \\
\hline 25.0 & $95.6 \pm 8.1^{\mathrm{a}}$ & $70.5 \pm 19.8^{\mathrm{a}}$ & $302 \pm 39^{a}$ & $79.6 \pm 5.3$ & $11.8 \pm 8.0$ & $498 \pm 100$ \\
\hline 30.0 & $84.8 \pm 6.0$ & $32.2 \pm 11.6$ & $294 \pm 35^{a}$ & $79.8 \pm 4.1$ & $11.6 \pm 7.6$ & $485 \pm 103$ \\
\hline 40.0 & $77.9 \pm 4.9$ & $19.0 \pm 5.7$ & $252 \pm 43^{\mathrm{a}}$ & $82.3 \pm 9.3$ & $9.6 \pm 5.6$ & $430 \pm 103$ \\
\hline 50.0 & $76.3 \pm 5.7$ & $22.5 \pm 8.2$ & $253 \pm 42^{a}$ & $75.2 \pm 9.8$ & $11.2 \pm 5.8$ & $494 \pm 116$ \\
\hline 60.0 & $81.8 \pm 4.3$ & $15.2 \pm 6.1$ & $295 \pm 32^{\mathrm{a}}$ & $76.0 \pm 9.2$ & $10.0 \pm 5.5$ & $506 \pm 75$ \\
\hline 90.0 & $74.9 \pm 4.3$ & $11.2 \pm \quad 3.4$ & $402 \pm 41$ & $72.8 \pm 3.5$ & $8.8 \pm 4.8$ & $536 \pm 110$ \\
\hline
\end{tabular}

$\mathrm{a}=$ Significant differences from the initial value.

Table 4. Time order of the IRI and glycemic maxima in the different tests. The times to the end of administered dose [min] are given. The data for $1.0 \mathrm{~g} / \mathrm{kg}$ glucose orally were taken from Fischer et al. 1972. The first peak in the OGTT after mucosal anaesthesia seems to correspond to the second peak in a normal OGTT and accordingly the second peak after mucosal anaesthesia is related to the third peak in the normal test

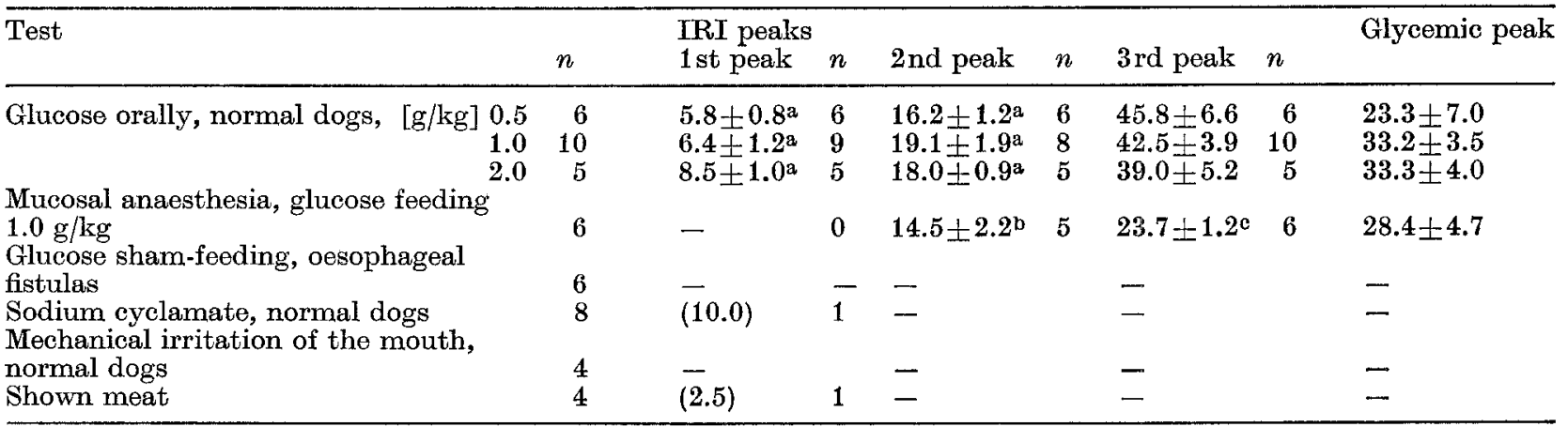

$\mathrm{a}=$ Significant difference from the next maximum in that test.

$\mathrm{b}=$ Significant difference from the first maximum in the normal tests.

$c=$ Significant difference from the preceding maximum in that test and from the third maximum in the normal test.

Table 5. Extent of the IRI and glycemic maxima in the different tests. The differences between the peak and the initial values $[\mu U / \mathrm{ml}]$ respectively $[\mathrm{mg} / 100 \mathrm{ml}]$ are given. Number of experiments and number of peaks see Table 4. Tests without any peak have not been repeated

\begin{tabular}{|c|c|c|c|c|}
\hline $\begin{array}{l}\text { Test } \\
\text { Glucose orally, normal dogs }\end{array}$ & $\begin{array}{l}\text { IRI peaks } \\
\text { 1st peak }\end{array}$ & 2nd peak & $3 r d$ peak & Glycemic peak \\
\hline $\begin{array}{l}0.5 \mathrm{~g} / \mathrm{kg} \\
1.0 \mathrm{~g} / \mathrm{kg} \\
2.0 \mathrm{~g} / \mathrm{kg} \\
\text { Mucosal anaesthesia, glucose } \\
\text { feeding } 1.0 \mathrm{~g} / \mathrm{kg} \\
\text { Sodium cyclamate, normal dogs } \\
\text { Shown meat }\end{array}$ & $\begin{array}{l}29.7 \pm 8.2 \\
30.2 \pm 6.0 \\
21.0 \pm 7.7 \\
-\quad \\
(30) \\
(36)\end{array}$ & $\begin{array}{l}55.5 \pm 15.1 \\
40.2 \pm 4.4 \\
29.2 \pm 8.2\end{array}$ & $\begin{array}{l}40.2 \pm 7.2 \\
50.8 \pm 8.4 \\
45.8 \pm 5.6\end{array}$ & $\begin{array}{l}36.2 \pm 6.1^{\mathrm{a}} \\
51.4 \pm 13.9 \\
56.8 \pm 4.9\end{array}$ \\
\hline
\end{tabular}

$\mathrm{a}=$ Significant difference to the tests with $2.0 \mathrm{~g} / \mathrm{kg}$. 
tion from the 5 th to the 10 th $\mathrm{min}$ in all tests with the same time pattern. The maximum values as well as the speed of decrease was related to the dose of glucose. This can be seen from the integrated response area (Table 2, column 3).

The early IRI increase was independent of the administered quantity of glucose. It began in all test groups at about $5 \mathrm{~min}$ and was of similar magnitude up to $25 \mathrm{~min}$. Only in the later phase did the differences indicate a relation between the mean insulin concentration and the glycemia resulting from the enteral $a b$ sorption. It can be seen from the integrated response areas (Table 2 , column 4 ) that the differences were small and insignificant. The insulinogenic indices (Table 2, column 6) showed a distinct diminution with increasing concentration of blood glucose . After $2.0 \mathrm{~g} /$ $\mathrm{kg}$ the insulinogenic indices were in a similar range to those after intravenous glucose administration (Fischer et al., 1972). But the various IRI peaks were similar to each other (see Table 4 and 5). The differences in the effects of the insulin responses were more obvious in the decrease of FFA (Table 2, column 5) than in the IRI concentrations themselves. The greater integrated response areas were due to both a more precipitous and a longer decrease.

In further tests the phase of insulin secretion that was independent of hyperglycemia was studied under the influence of superficial anaesthesia of the mucosal nerves in the mouth. The animals tolerated the application of tetracain quietly. In most cases there was a loss of about $25 \%$ of the administered glucose due to the paralysis of swallowing. Therefore, after glucose feeding there was a diminution of the blood glucose curve (Table 3 ) and of the integrated response area (Table 2, column 3). Nevertheless it seemed to be important that the insulin secretion phase that was independent of the rise in blood glucose was absent or at least delayed. In Table 2 the decrease of the IRI-area, of the insulinogenic index, and of the integrated FFA response area can be seen. The analysis of the IRI-maxima in the individual experiments (Tables 4 and 5) gave the same result. In accordance with these observations shamfeeding of glucose (recovery $93.7 \pm 4.0 \%$ ) after similar mucosal anaesthesia did not produce any alteration in the parameters investigated. There was no reflex insulin mobilization. The immediate IRI-increase of the normal animals was absent both after mucosal anaesthesia and after "bypassing" the cavity of the mouth.

The production by a drug, of the taste "sweet" (Fig. 1) did not produce any alteration in these three parameters. There was no integrated response area significantly different from zero. Only one out of the eight animals showed an early IRI peak (Table 4 and 5). This peak does not influence the statistical mean of the whole group. The slight and continual rise of FFA agreed with our earlier findings (Fischer et al., 1972) and possibly reflects some irritation by the test procedure despite training measures.
Finally it must be taken into consideration that either by training or by the daily feeding regime, a conditioned reflex could be produced that evokes insulin secretion after arranging the test situation or after preparation of the meals. During the training programme, however, neither insulin nor known insulinogenic metabolically active substances were given. Fig. 2 shows that in both groups the exposure of meat or mechanical irritation of the mouth induced no IRI increase. In these control studies all alterations of

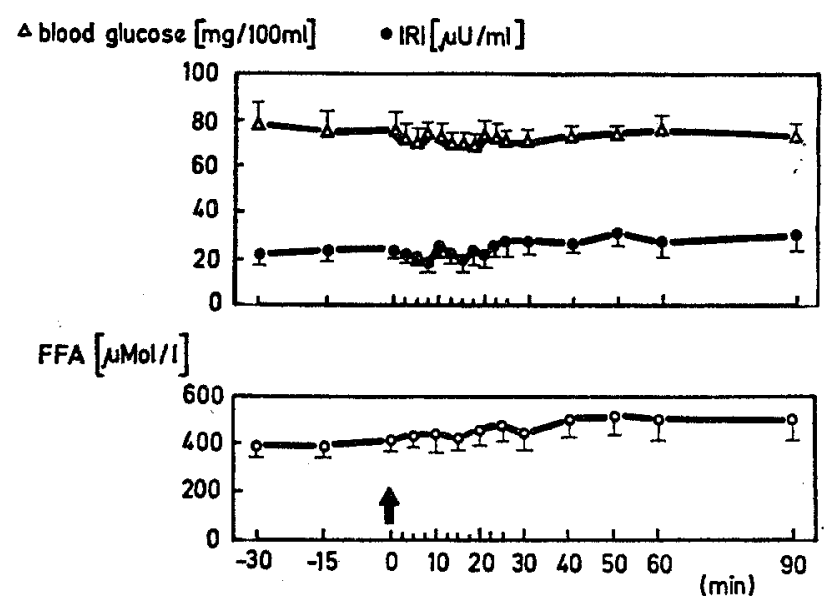

Fig. 1. Blood sugar ( $\Delta$ ), IRI ( ) and FFA (o) concentra. tions in the peripheral venous blood of intact dogs after spraying sodium cyclamate powder in the cavity of mouth $(n=8)$

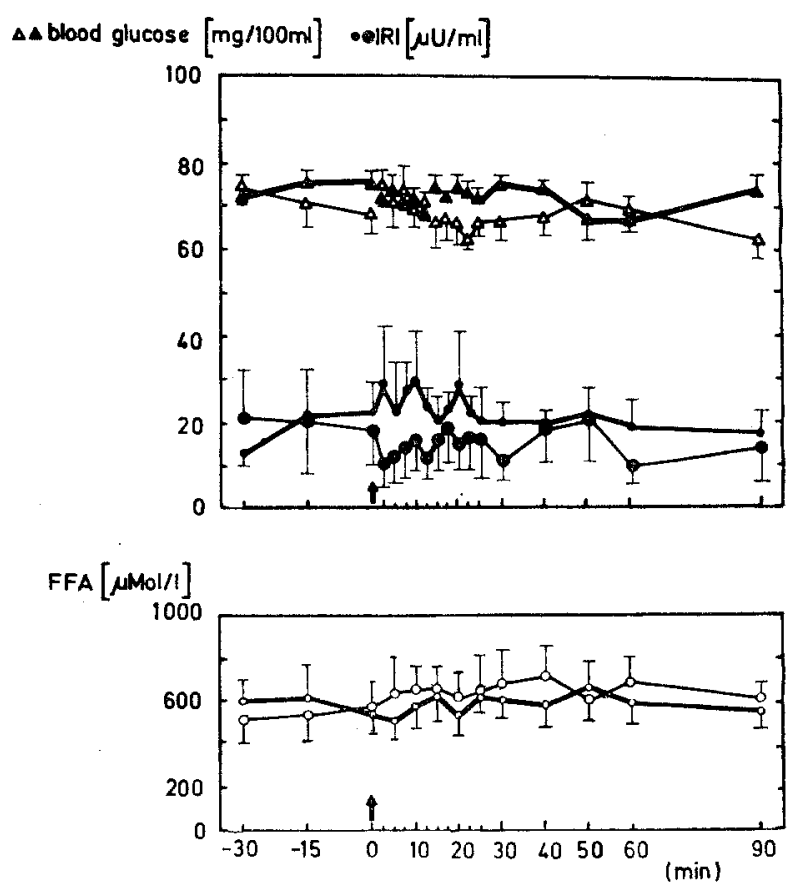

Fig. 2. Blood sugar, IRI, and FFA concentrations in the peripheral venous blood of intact dogs after showing them a meal of meat (thick line, $n=4$ ) or after mechanical irritation of the mouth (thin line, $n=4$ ). Symbols ef. legend of Fig. 1 
glycemia, IRI, or FFA were not significant and all integrated areas could not be distinguished from zero.

The slight FFA increase combined with a slight IRI decrease in the group with mechanical irritation seemed to be produced by stress. No animal with "mechanical irritation" and only one out of four animals which were shown a meal reacted with a transient IRI peak (Table 4 and 5). All dogs of this group showed appropriate behavioural responses with excitement and salivation. Similar results were obtained in dogs that were adapted for several months to a "five times a day feeding regime". They were submitted to a sham feeding situation under indentical conditions, but without administration of the meal; no IRI response occured.

\section{Discussion}

Food ingestion is the most repeated physiological stimulus to the insulin 'producing and releasing' unit. It has been shown that there is more insulin secreted after oral rather than intravenous glucose (Karamanos et al., 1971; Elrick et al., 1964). The vegetative nervous system (especially the N.vagus) as well as the enterohormones are probably involved in these phenomena. These differences do not occur when atropine is given (Kaess et al., 1970). They are also absent if the exocrine pancreas does not function normally (Goberna et al., 1971). Intact exocrine pancreatic function is essential for the effect of gastrin and secretin on insulin secretion. These observations and our findings suggest a reflex mechanism involved in the early phase and in the augmentation of insulin secretion by oral administration. The afferent and the efferent reflex arc may consist both of nervous and of hormonal functions. It is well known that the parasympathetic (Nelson et al., 1967; Frohman et al., 1967), the sympathetic (Imura et al., 1971; Burr et al., 1971) and in some cases also the central (King et al., 1971) nervous systems are regulating units in the basal as well as in the stimulated insulin secretion. The enterohormones, two of which may be especially involved in the efferent part of such a "feed-forward" of insulin secretion (gastrin: Grossman, 1970; Byrnes, 1970, secretin: Gregory, 1962) may also be released by reflex mechanisms.

Our results presented here suggest that the factors stimulating IRI-secretion independent of hyperglycemia do not depend on the administered amount of glucose. The evidence with lower doses of glucose in OGTTs with IRI measurements seems to be better than that of higher doses, (Förster et al., 1970, Castro et al., 1970), similar to the administration of meals with different caloric values (Deller et al.,1970).

The investigations described in the second part of this paper may contribute to the understanding of the afferent branch of the suggested insulinogenic reflex. When considering the experiments with mucosal anaesthesia the effects of stress the possible widespread effects of local anaesthesia must be taken into consideration.

Nervertheless the elimination of the early phase of IRI increase after feeding and the lack of any insulin secretion after sham-feeding seems likely to be due to paralysis of the nerve endings in the cavity of mouth. Therefore it is presumed that at least one part of the first IRI peak(s) is initiated via nervous receptors in the mouth. There are analogous effects of superficial duodenal mucosal anaesthesia on the exocrine pancreatic function (Thomas and Swena, 1963; Schapiro and Woodward, 1962; Thambugala and Baron, 1971).

In accordance with the results of Goldfine et al., (1969) it can be concluded that the stimulation of the "sweet-receptors" does not stimulate any insulin secretion. It is not possible to generalize to all taste receptors, since the sweet taste in most dogs (except the so-called luxury dogs) does not elicit behavioural preference reactions. Finally we acknowledge the possibility of influencing insulin secretion by inducing a conditioned reflex (Woods et al., 1970, Mitjuschow, 1964; Hutton et al., 1970) or by hypnosis (Goldfine et al., 1970), but our control experiments seem to exclude that the early IRI increase after giving glucose orally could have been produced by such a mechanism.

The authors are grateful to Mrs. Karla Brüllke, Mrs. Helga Schröder, Miss Gisela Schmidt and Miss Helga Schüler for careful technical assistance.

\section{References}

1. Burr, I. M., Balant, L., Stauffacher, W., Renold, A.E. : Adrenergic modification of glucose-induced biphasic insulin release from perifused rat pancreas. Europ. J. clin. Invest. 1, 216-224 (1971).

2. Bymes, D.J., Lazarus, L., Young, J.D.: Effect of vagotomy on serum gastrin in patients with duodenal ulcer. Ann. Med. 19, 240-244 (1970).

3. Castro, A., Scoto, J.P., Grettie, D.P., Macfarlane, D., Bailey, R.E.: Plasma insulin and glucose responses of healthy subjects to varying glucose loads during three-hour oral glucose tolerance test. Diabetes 19, $842-851(1970)$.

4. Deller jr., J.J., Sailor, J.L., Hutsell, T.C., DiRaimondo, V.C.: Effects of dietary alterations on insulin secretion in normal individuals. Milit. Med. 135, $631-$ $636(1970)$.

5. Dupré, J.: Regulation of the secretions of the pancreas. Ann. Rev. Med. 21, 299-316 (1970).

6. Dupré, J.: Effect ot route of administration on dis posal of glucose loads. J. Physiol. (Lond.) 175, 58P $60 \mathrm{P}$ (1964).

7. Elrick, H., Stimnaler, L., Hlad, C.H., Arai, Y.: Plasma insulin response to oral and intravenous glucose administration. J. clin. Endocr. 24, 1076-1082 (1964).

8. Fischer, U., Hommel, H.: Insulinmobilisierung beim Hund nach Scheinfütterung mit Glucose. Experientia 27,397 (1971).

9. Fischer, U., Hommel, H., Ziegler, M., Michael, R.: The mechanism of insulin secretion after oral glucose administration. I. Multiphasic course of insulin mobilization after oral administration of glucose in conscious trained dogs. Differences to the behaviour after intravenous administration. Diabetologia 8, 104-110 (1972). 
10. Förster, H., Haslbeck, M., Geser, C.A., Mehnert, H. Blutglucose und Seruminsulin nach oraler Applikation von Glucose und Stärkesirup in unterschiedlicher Dosierung. Diabetologia 6, 482-487 (1970).

11. Frohman, L.A., Ezdinli, E., Javid, R.: Effect of vagotomy and vagal stimulation on insulin secretion. Diabetes 16, $443-448$ (1967).

12. Goberna, R., Fußgänger, R.D., Raptis, S., Telib, M. Pfeiffer, E.F.: The role of the exocrine pancreas in the stimulation of insulin secretion by intestinal hormones. II. Insulin response to secretin and pancreozymin in experimentally-induced pancreatic exocrine insufficiency. Diabetologia 7, 68-72 (1971).

13. Goldfine, I.D., Ryan, W.G., Schwartz, T.: The effect of glucola, diet cola and water ingestion on blood glucose and plasma insulin. Proc. Soc. exp. Biol. 131, $329-330$ (1969).

14. Goldfine, I.D., Abraira, C., Grunewald, D., Goldstein, M.S.: Plasma insulin levels during imaginary food ingestion under hypnosis. Proc. Soc. exp. Biol. 133, $274-276(1970)$.

15. Gregory, R.A.: Secretory mechanisms of the gastrointestinal tract, p. 135. London: E. Arnold Publ. Ltd. 1962.

16. Grossman, M.I.: Gastrin and its activities. Nature 228, $1147-1150$ (1970).

17. Hommel, H., Fischer, U., Retzlaff, K., Knöfler, M.: The mechanism of insulin secretion after oral glucose administration. II. Reflectory insulin secretion in conscious dogs bearing fistulas of the digestive tract by sham-feeding of glucose or tap water. Diabetologia $8,111-115$ (1972).

18. Hutton, R.A., Woods, S.C., Makous, W.L.: Conditioned hyperglycemia: pseudoconditioning controls. J. comp. physiol. Psychol. 71, 198-202 (1970).

19. Imura, H., Kato, Y., Ikeda, M., Morimoto, M., Yawata, M. : Effect of adrenergic blocking or - stimulating agents on plasma growth hormone, immunoreactive insulin and blood free fatty acid levels in man. J. clin. Invest. 50, 1069-1079 (1971).

20. Kaess, H., Schlierf, G., Mikulicz-Radecki, J. v.: Die Einwirkung von Atropin auf dio glucose- und sekretin- induzierte Insulinsekretion. Verh. dtsch. Ges. inn. Med. 76, 390-393 (1970).

21. Karamanos, B., Butterfield, W. J.H., Asmal, A.C., Whichelow, M.J.: The pattern of early insulin response to oral glucose. Postgrad. Med. J. Suppl. 1971, $440-443$ (1971).

22. King, L.R., Knowles, H.C., jr., McLaurin, R.C., Lewis, H.P.: Glucose tolerance and plasma insulin in cranial trauma. Ann. Surg. 173, 337-343 (1971).

23. Mitjuschow, M.J.: Cerebral cortical function and blood sugar level (russ.). Moskau, Leningrad: Verlag der Wissenschaften 1964.

24. Nelson, N.C., Blackard, W.G., Cocchiara, J.C., Labat, A.J.: Influences of the vagus nerves on pancreatic insulin secretion. Diabetes 16, 852-857 (1967).

25. Porte, D., jr., Bagdade, J.D.: Human insulin secretion: an integrated approach. Ann. Rev. Med. 21, $219-240(1970)$.

26. Schapiro, H., Woodward, E.R.: Inhibition of secretin mechanisms with local anaesthetics. Physiologist 5, $208-213(1962)$.

27. Seltzer, H.S., Allen, E.W., Herrea, A.L., Brennan, M.T.: Insulin secretion in response to glycaemic stimulus, relation of delayed initial release to carbohydrate intolerance in mild diabetes mellitus. $J$. clin. Invest. 46, 323-335 (1967).

28. Thambugala, R.L., Baron, J.H.: Pancreatic secretion after selective and truncal vagotomy in the dog. Brit. J. Surg. 58, 839-845 (1971).

29. Thomas J.E., Swena, E. M.: The effect of local anaesthetic applied to the intestinal mucosa. Fed. Proc. 22, $664-668$ (1963).

30. Woods, S.C., Hutton, R. A., Makous, W.: Conditioned insulin secretion in the albino rat. Proc. Soc. exp. Biol. 133, 964-968 (1970).

Dr. U. Fischer

Zentralinstitut für Diabetes

"Gerhard Katsch"

Bereich experimentelle Forschung

DDR+2201 Karlsburg

German Democratic Republic 